J. Clin. Chem. Clin. Biochom.

Vol. 17, 1979, pp. 29-34

\title{
Inımuno-chemical Studies on the Alkali-labile Carbohydrate Chains of Human Serum Glycoproteins
}

\author{
By G. Uhlenbruck, I. Reese, P. Vaith and H. Haupt \\ Medical University-Clinic Cologne and Behringwerke AG, Marburg, Germany
}

(Received May 15/July 25, 1978)

Summary: Human serum glycoproteins can be classified into those containing $\mathrm{N}$-acetyl-D-galactosamine and into those lacking this hexosamine. The $\mathrm{N}$-acetyl- $D$-galactosamine-containing serum glycoproteins have alkali-labile chains containing this hexosamine linked O-glycosidically to hydroxy amino acids. These alkali-labile chains can be demonstrated in neuraminic acid free serum glycoproteins by gas liquid chromatography and by using precipitating lectins from invertebrates and plants. They are represented by two chains, one containing only $N$-acetyl-D-galactosamine, the other with $D$-galactose linked $(1-3) \beta$-glycosidically to this hexosamine forming a disaccharide. Scrologically these two chains, which usually occur together on one molecule, can be characterized by their reaction with lectins from Helix pomatia (anti-A like) and from Agaricus bisporus and Arachis hypogaea (anti-TF specificity).

\section{Immunchemische Untersuchungen an alkali-labilen Kohlenhydratketten menschlicher Serum-Glykoproteine}

Zusammenfassung: Menschliche Serum-Glykoproteine kann man in zwei Gruppen einteilen, nämlich solche, wclche $\mathrm{N}$-Acetyl-D-Galactosamin enthalten, und in solche, die dieses Hexosamin nicht besitzen. Die N-Acetyl-D-Galactosamin enthaltenden Serum-Glykoproteine haben diesen Aminozucker O-glykosidisch an Hydroxy-Aminosäuren gcbunden. Man kann diese alkali-labilen Ketten in neuraminsäure-freien Glykoproteinen des Serums nachweisen und zwar mit Hilfe der Gaschromatographie und durch präzipitierende Lektine aus Invertebraten und Pflanzen. Sie bestehen aus zwei Ketten-Typen, eine davon enthält nur N-Acetyl-D-Galactosamin, während die andere noch $D$-Galactose $(1-3)$ $\beta$-glykosidisch an dieses Hexosamin gebunden besitzt, so daß ein Disaccharid entsteht. Serologisch können diese beiden Ketten, die in der Regel gemeinsam auf einem Molekül vorkommen, durch ihre Reaktionen mit den Lektinen aus Helix pomatia (Anti-A ähnlich) und denen aus Agaricus bisporus und Arachis hypogaea (Anti-TF Spezifität) charakterisiert werden.

\section{Introduction}

In foregoing papers of this series concerning the chemical structure and the serological role of human asialo serum glycoprotein oligo-saccharide chains, we have already investigated and described:

1. The reaction of neuraminic acid-free serum glycoproteins with various, mainly anti- $\beta$ - $D$-galactosyl specific lectins (1).

2. The fact that some of these lectin receptors are identical with two alkali-labile bound carbohydrate chains: Chain I consisting of the disaccharide $\beta-D$ galactosyl-(1-3)-N-acetyl-D-galactosamine, and chain II represented by $\alpha$-linked $N$-acetyl- $D$ galactosamine. Both chains are bound O-glycosidically to serine or threonine of the protein backbone (2).

3. These two chains could be clearly identified by their specific reaction with special purified lectins: Chain I reacts with the lectins from Arachis hypogaea (peanut receptor or TF-antigen) and Agaricus bisporus, whereas chain II reacts with the one from Helix pomatia (the so-called 'A-like' receptor) (2).

In continuing this work, which has becn undertaken and planned in order to investigate the contribution of the different carbohydrate chains to the "liver clearance" and metabolism of asialo glycoproteins as suggested by Ashwell $(3,4)$, we have now focussed our research on the following problems, the results of which we will discuss here:

a) The distribution of alkali-stable and alkali-labile carbohydrate chains within the group of serum glycoproteins.

b) The chemical characterisation of the alkali-labile chains I and II by gas-liquid chromatography and

c) the serological confirmation of these data by using the specific lectins, mentioned already under point 3. 


\section{Material and Methods}

Material

Human serum glycoproteins were highly purified by Haupt et al. and obtained from Behringwerke AG, Marburg (West Germany).

Lectins: Their preparation is described in a previous paper (2).

\section{Techniques}

Gas liquid chromatography (GLC)

a) Analysis of hexoses and hexosamines

Glycoprotein samples $(2-3 \mathrm{mg}$ ) were hydrolysed in $3 \mathrm{~mol} / 1$ $\mathrm{HCl}$ at $100^{\circ} \mathrm{C}$ for 4 hours. After adding $30 \mu \mathrm{g}$ erythritol as an internal standard, the solution was "neutralized" by $\mathrm{AgNO}_{3}$, the sediment was removed by centrifugation and washed 3 times with distilled water. The combined supernatant and washings were lyophilized and then reacetylated by incubation with acetic anhydride for $16 \mathrm{~h}$ at room temperature (5). After relyophilization the sample has to stay in vacuo over $\mathrm{CaCl}_{2}$ for $24 \mathrm{~h}$. In order to prepare the samples for analysis in the gas-liquid chromatograph, they were trimethylsilylated for $30 \mathrm{~min}$, as described by Sweeley et al. (6), except we used hexamethyldisilazane and trimethylchlorosilane in the reaction mixture.

The data of the gas-liquid chromatograph we used and the cordition of the analysis have been described in a previous paper (7).

b) Analysis of the disaccharide

The glycoproteins were desialylated by mild acid hydrolysis (incubation with $0.05 \mathrm{~mol} / 1 \mathrm{H}_{2} \mathrm{SO}_{4}$ for $1 \mathrm{~h}$ by $80^{\circ} \mathrm{C}$ ) followed by alkaline borohydride treatment as performed by Newman et al. (7). The disaccharide content of the gly coproteins was assayed by GLC in the same way as the monosaccharides, except that they were trimethylsilylated for $2 \mathrm{~h}$ and chromatographed isothermally at $250^{\circ} \mathrm{C}$ with trehalose as an internal standard.

c) Estimation of alkali-labile bound $\mathrm{N}$-acetyl-galactosamine This procedure was performed analogous to the disaccharide analysis by mild acid hydrolysis and subsequent alkaline borohydride treatment, by which the $\mathrm{N}$-acetyl-galactosamine is converted into galactosaminitol, which can be detected by GLC (temperature programme $125^{\circ} \mathrm{C}-230^{\circ} \mathrm{C}$, increasing $4^{\circ} \mathrm{C} / \mathrm{min}$ ), internal standard: instead of trehalose ery thritol.

\section{Chemical analysis of sialic acid}

The sialic acid ( $\mathrm{N}$-acetyl-neuraminic acid) was estimated by using Bial's orcinol reagent (8). $\mathrm{N}$-acetyl-neuraminic acid was taken as a standard.

\section{Haemagglutination inhibition assay}

The assay was performed by using the Cooke serial dilution microtitre system (Cooke Instruments, Zollikon, Switzerland).

Red cells were treated with neuraminidase for this purpose and desialylated serum glycoproteins were used. The latter was achieved by incubating $5 \mathrm{mg} / \mathrm{ml}$ protein in saline with $50 \mu \mathrm{l}$ neuraminidase (500 units/ml, Behringwerke AG, Marburg) for $1 \mathrm{~h}$ at $37^{\circ} \mathrm{C}$. The test red cells were made up to a $2 \%$ suspension in saline (erythrocytes of group 0 were taken from a single. "standard" person) after they had been treated with neuraminidase ( $200 \mu \mathrm{l}$ neuraminidase to $20 \mathrm{ml} 2 \%$ red cell suspension) for $1 \mathrm{~h}$ at $37^{\circ} \mathrm{C}$ and washed three times with saline.

The concentration of the lectins was prepared in such a way, that a dilution of an agglutinatory dose of $1: 4$ still gave a good clumping picture. The haemagglutination inhibition assay titer was defined as the minimum amount of substance inhibiting the agglutination of red cells by the lectin at an agglutinatory dosis of 4 .

\section{Results}

The monosaccharide analysis of all investigated serum glycoproteins is listed in table 1. According to this table one may classify serum glycoproteins into two groups: one group containing $\mathrm{N}$-acetyl- $D$-galactosamine, the other not. We could find no serological (lectins), or gas chromatographic evidence for the occurrence of alkali-labile carbohydrate chains in the last group. By definition, alkali-labile carbohydrate chains are linked via $\mathrm{N}$-acetyl- $D$-galactosamine either to serine or to threonine O-glycosidically; thus this last group does not contain any alkali-labile carbohydrate chains and was excluded from further experiments.

Accordingly, as has been outlined in figure 1, we investigated only the first group of serum glycoproteins, namely those containing $\mathrm{N}$-acetyl- $\ddot{D}$-galactosamine. As shown by the presence of $\mathrm{N}$-acetyl- $D$-glucosamine and $D$-mannose, typical markers for alkali-stable carbohydrate chains, alkali-stable carbohydrate chains are also formed in these glycoproteins.

The presence of alkali-labile carbohydrate chains I and II was then verified by serological and chemical methods in this class of glycoproteins. The results of our experiments are documented in table 2 and 3 . However there is no true relationship between the total content of $\mathrm{N}$-acetyl-D-galactosamine and the quantity of the same hexosamine as quantitatively detected in the two alkali-labile chains. This mis-relation must be attributed to the alkaline borohydride treatment of the glycoproteins, which leads to a so-called "peeling-reaction" by more or less splitting $\mathrm{N}$-acetyl- $D$-galactosamine molecules into pieces, which can no longer be identified by $\operatorname{GLC}(9,10,11)$.

The results of our investigations (as shown in tables 2 and 3) can be summarized as follows:

1. Of the 32 human serum glycoproteins we investigated only nine contain $\mathrm{N}$-acetyl- $D$-galactosamine-containing alkali-labile carbohydrate chains. In the native state, these residues will be more or less or even completely, substituted or serologically blocked by $\mathrm{N}$-acetylneuraminic acid (2). The other serum glycoproteins do not contain such structures.

2. With the exception of $\alpha_{2}$ HS-glycoprotein, all these asialo-glycoproteins react with lectins from peanut, Arachis hypogaea, in the precipitin reaction (2). In the haemagglutination inhibition assay, fetuin, $\beta_{2}$-glycoprotein III and IgD do not exhibit any inhibition, obviously due to the small amount of the TFdisaccharide chain I (see introduction), whereas in the agar gel diffusion much higher concentrations can be used and have been used (up to 5\%). On the other hand, the competing TF-receptor on the erythrocyte surface, has been shown to have a much higher affinity to the lectin than the few groups on the inhibitory substance. Serological unreactivity. may also be due to steric or topochemical reasons. . . 
Tab. 1. Carbohydrate content of some human serum glycoproteins in $\%$.

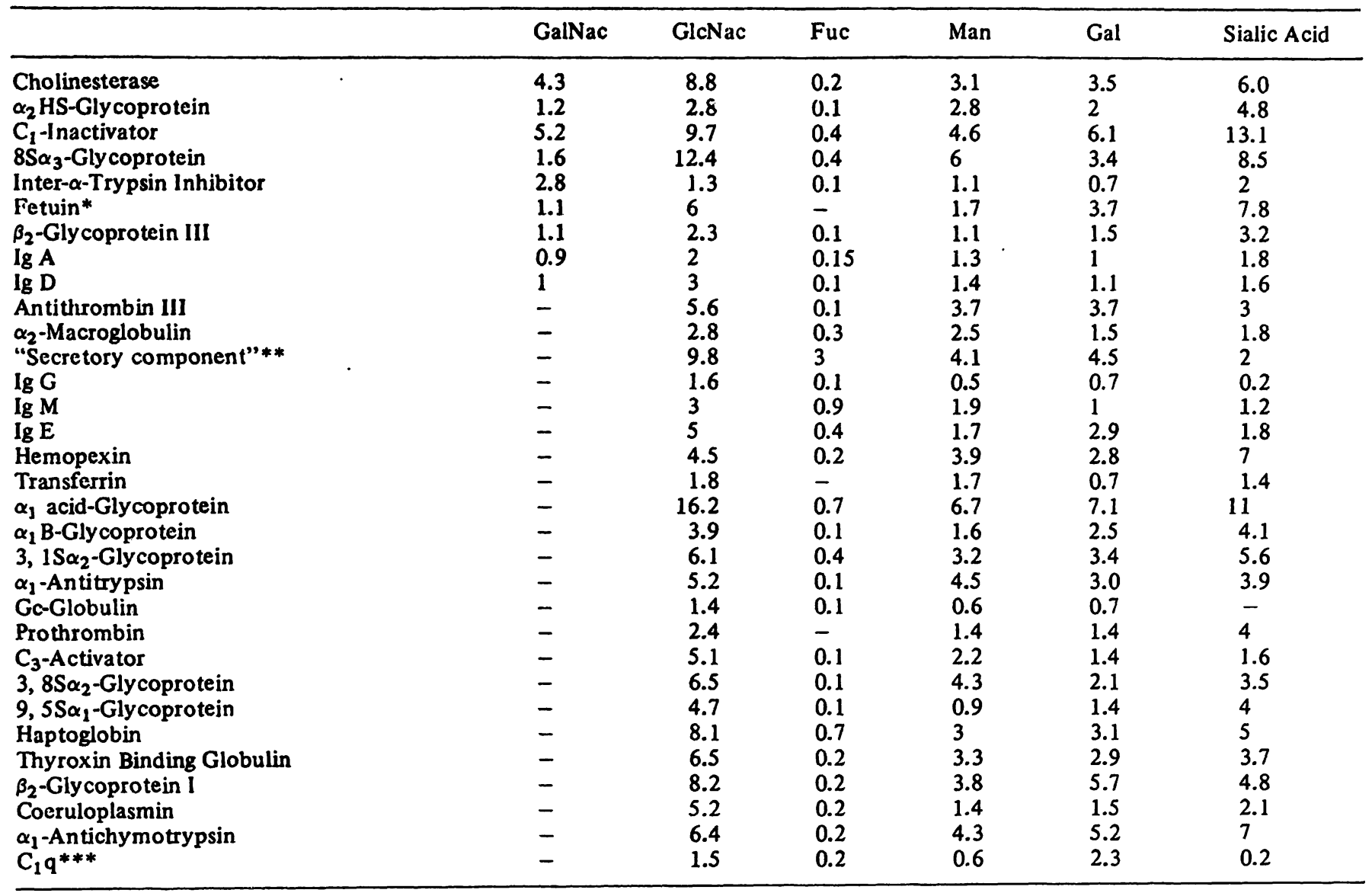

* Fetuin is taken from fetal calf serum

** Secretory component is taken from human colostrum

*** $C_{1} q$ also contains $2.2 \%$ glucose

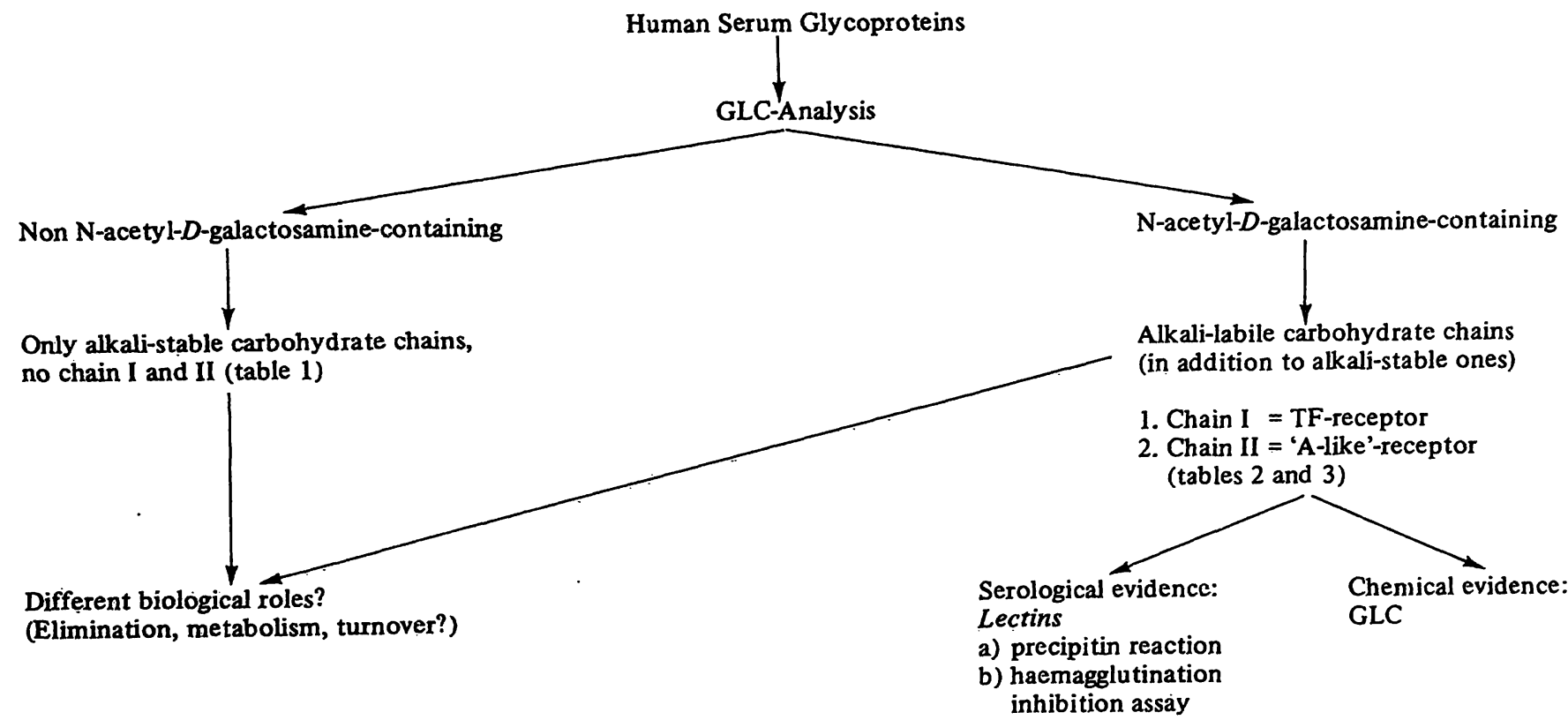

Fig. 1. Alkali-stable and alkali-labilc carbohydrate chains of human serum glycoproteins.

As can be deduced from table 2 and 3 , all serum glycoproteins, with the exception of $\alpha_{2}$ HS-glycoprotein and Ig D of the right group have both types of alkali-labile chains. 
Tab. 2. Carbohydrate chains in different $\mathrm{N}$-acetyl-D-galactosamine-containing desialylated human serum glycoproteins.

\section{A. The TF-Receptor}

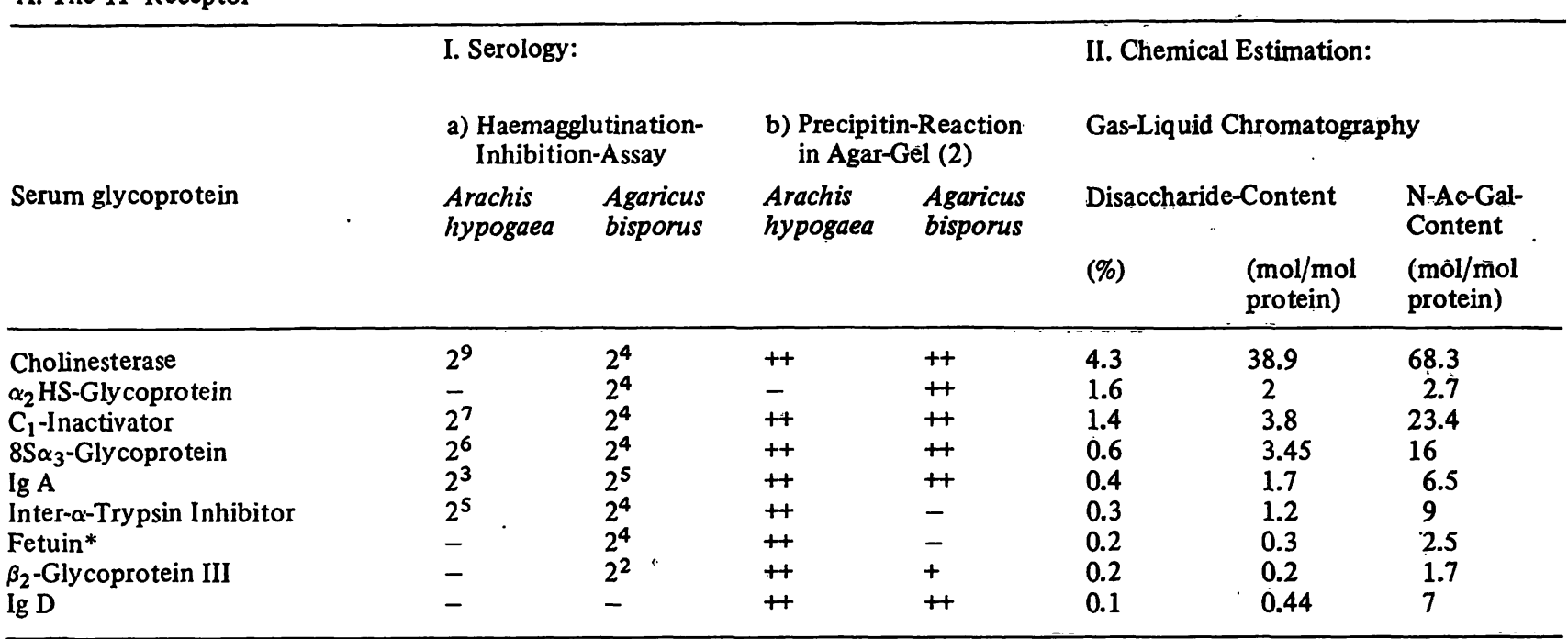

* Fetuin is taken from fetal calf serum

Structure suggested for the receptor of the lectins from Arachis hypogaea and Agaricus bisporus:

$\beta$ - $D$-galactosyl(1-3)-N-acetyl- $D$-galactosamine $\rightarrow$ serine (threonine)

Tab. 3. Carbohydrate chains in different $\mathrm{N}$-acetyl- $D$-galactosamine-containing desialylated human serum glycoproteins.

B. The 'A-like'-Receptor

\section{Serology:}

a) HaemagglutinationInhibition-Assay

Serum glycoprotein
Helix pomatia
II. Chemical Estimation

Gas-Liquid Chromatography

b) Precipitin-Reaction in Agar-Gel (2)

Helix pomatia
Galactosaminitol-Content

(\%) $\quad(\mathrm{mol} / \mathrm{mol}$

\begin{tabular}{lllll} 
& & & protein) \\
\hline Cholinesterase & $2^{2}$ & + & 1.6 & 25 \\
$\alpha_{2}$ HS-Glycoprotein & - & - & - & - \\
C -Inactivator & $2^{2}$ & - & 0.1 & 0.5 \\
8 S $\alpha_{3}$-Glycoprotein & $2^{1}$ & - & 0.16 & 1.6 \\
Ig A & $2^{3}$ & - & 0.05 & 0.4 \\
Inter- $\alpha$-Trypsin Inhibitor & $2^{1}$ & - & 0.1 & 0.7 \\
Fetuin* & - & - & 0.1 & 0.2 \\
$\beta_{2}$-Glycoprotein III & - & - & - & 0.2 \\
Ig D & - & & - \\
\hline
\end{tabular}

\footnotetext{
* Fetuin is taken from fetal calf serum
}

Structure suggested for the receptor of the lectin from Helix pomatia: $\alpha-\mathrm{N}$-acetyl- $D$-galactosamine $\rightarrow$ serine (threonine)

3. Only IgD and $\alpha_{2}$ HS-glycoprotein have one type of alkali-labile carbohydrate chain, namely the TFreceptor ( $\beta$ - $D$-galactosyl-(1-3)-N-acetyl- $D$-galactosamine) of chain $\mathrm{I}$, whereas all the others also have the chain II type, namely the 'A-like'-N-acetyl- $D$ galactosaminyl-receptor. Both chains can be detected chemically by GLC and serologically by the precipitin reaction or haemagglutination inhibition with specific lectins: all three methods allow a clear cut characterization and estimation of the alkali-labile carbohydrate chains of serum glycoproteins.

\section{Discussion}

The classification of serum glycoproteins into two groups, namely those with alkali-labile carbohydrate chains and those lacking them, offers some new aspects for the metabolism, secretion, turnover and the "liver clearance" mechanism as postulated by Ashwell's experiments (fig. 1). It not only contributes new information on the biochemical structure of the carbohydrate part of the different serum glycoproteins, but it raises once again the question of the biological role . of the sugar side chains. 


\section{CAMAG}

\section{Elektrophorese-Scanner} + Elektrophorese-Integrator

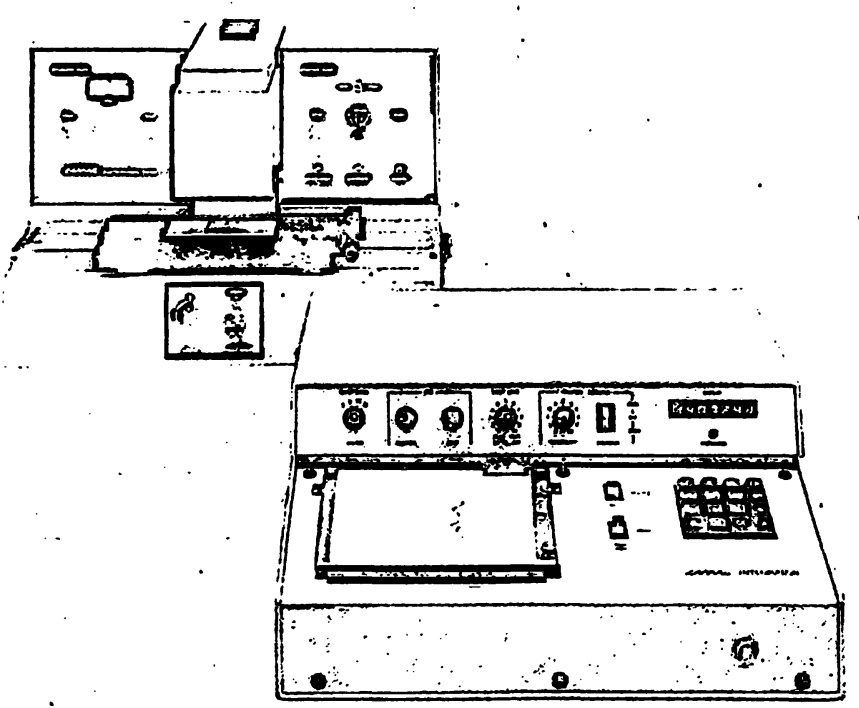

Eine vollautomatische Auswerteeinheit mit grossem Bedienungskomfort

- Alle im Klinischen Labor anfallenden Trennungen können problemlos ausgewertet werden, z. B. Serumproteine, Lipoprotëine, Mèmbranfolien, Gelschichten oder Disc-Röhrichen.

- Das Messobjekt ist während der Messung sichtbar, daher leicht zu kontrollieren.

- Der Scanner misșt wahlweise im Durchlicht oder Aưflichit, jẽ ñächdèm, was für das Messobjekt vorteilhafter: ist:

(3) Auf dem gleichen Blatt werden Patientenidentifizieruñg, Auswertekurve und digitales Érgebnis ausgedruckt, praxisgerecht und in Sekundenschnelle.

Ein bedienungsfreundlictés Gérat fữr die Routine, jedoch mit Forschuingsqualität.

Verlangen Sie ausführliche Informatioñen oder glejch eine Vorführung!

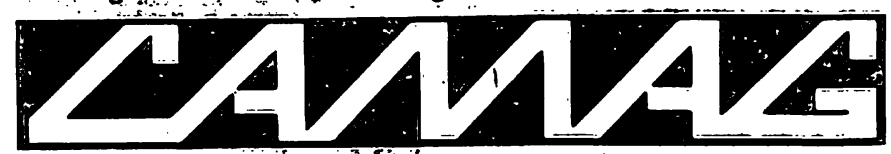

Homburgerstrasse 24 4132 Mứttênz/Schiveiz . Tel: (061) 613434

Bismarckstrasse $27=29$ 1000 Berlin 41

Tel. (030). 7951091

80282-D
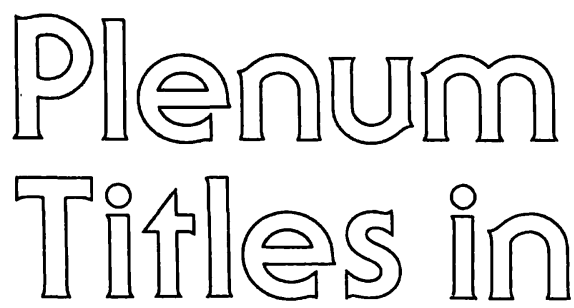

Clinical

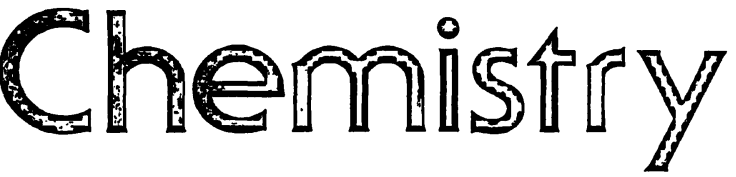

\section{Introduction to X-Ray Spectrometric Analysis} by Eugene P. Bertin

RCA Laboratories

500 pp., illus., $1978, \$ 28.50$

An Introduction to Microscopy by Means of Light, Electrons, X-Rays, or Ultrasound

by Theodore George Rochow

North Carolina State University at Raleigh

and Eugene George Rochow

Harvard University

384 pp., illus., $1978, \$ 29.50$

Transition States of Biochemical Processes edited by Richard D. Gandour

Louisiana State University

and Richard L. Schowen

University of Kansas

636 pp., illus., 1978, $\$ 49.50$

\section{Applied}

\section{Atomic Spectroscopy}

edited by E. L. Grove

IIT Research Institute

Volumes in Modern Analytical Chemistry

Volume 1: 331 pp., illus., 1978, $\$ 39.50$

Volume 2: 364 pp., illus., 1978, $\$ 39.50$

Two-volume set: $\$ 75.00$

Prices slightly higher outside the U.S.

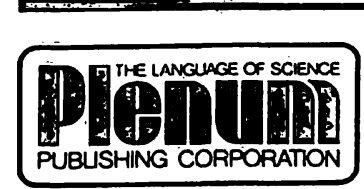


A. W. Norman et al. (Editors)

\section{A. W. Norman et al. (Editors)}

\section{Vitamin D and Problems Related to Uremic Bone Disease}

Proceedings of the Second Workshop on Vitamin D, Wiesbaden, West Germany, October 1974.

Editors: A. W. Norman, K. Schaefer, H. G. Grigoleit, D. von Herrath, E. Ritz.

1975. $17 \mathrm{~cm} \times 24 \mathrm{~cm} . X X V I, 779$ päges.

With numerous illustrations. Bound DM 165,-; $\$ 78.60$

ISBN 3110057751

\section{Vitamin D}

\section{Biochemical, Chemical and Clinical Aspects Related to Calcium Metabolism}

Proceedings of the Third Workshop on Vitamin D, Asilomar, Pacific Grove, California, USA, January 1977.

Editors: A. W. Norman, K. Schaefer, J. W. Coburn, H. F. DeLuca, D. Fraser, H. G. Grigoleit, D. von Herrath.

$1977.17 \mathrm{~cm} \times 24 \mathrm{~cm}$. $X \mathrm{~L}, 973$ pages. With numerous figures.

Bound DM 175,-; $\$ 83,40$

ISBN 3110069180

These books give a survey of present knowledge and research on numerous facets of calcium and bone metabolism. The problems are presented and discussed from various standpoints (biochemists, clinicians, osteologists). In addition, a report is made on the latest vitamin $D$ research. The main point of these proceedings is the timeliness of each single contribution as well as the very informative summary of current problems of calcium metabolism, especially in reference to clinical aspects and perspectives. These books are of interest to those engaged in calcium metabolism, vitamin $D$ research, problems of chronic kidney insufficiency, general osteologic problems, and endocrinology.

Prices are subject to change without notice
Verlag Walter de Gruyter \& Co.

Genthiner Straße 13

D-1000 Berlin 30./ Germany

Tel. (030) 2611341
Walter de Gruyter, Inc. Publishers 200 Saw Mill River Road Hawthorne, N.Y. 10532 USA Phone (914) 747:0110 
One important feature of these asialo carbohydrate chains seems to be that they can be recognized by membrane-integrated vertebrate lectins; these specifically react with the $\beta$-galactosyl end-groups, which are normally hidden in a cryptic state (2). Our investigations thus find a solid basis for further studies in this direction. Experiments, which are already in progress, employ radioactive labelled asialo glycoproteins as a means of following their metabolism, their catabolism, their excretion and their clearance by certain organs, for instance the liver.

They also represent a basis for answering the questions, whether the subterminal or next sugars to the $\beta$-galactosylendgroups have any influence; and whether the anomeric linkage, or the carbohydrate chain itself (alkali-labile or alkali-stable) has any thing to do with the vertebrate lectin mediated trap mechanism of these glycosubstances. Finally, they serve as a biological model for studying the metabolism of other (e. g. membrane-bound and isolated membrane glycoproteins) glycosubstances containing one or both types of chains, or one or both of the alkalilabile chains (I and II).

This may also be of great interest with respect to: the trapping of neuraminidase-treated red cells; the "homing" of lymphocytes; the metastases of tumor cells with such a cryptic deletion of carbohydrates or asialo structures; and the interpretation of certain rosette-formation phenomena, in which glycoproteins may participate and membrane lectins may play a role (12).

Knowledge about the structure and distribution of such alkali-labile carbohydrate chains of type I and II, and their different substitution by sialic acids, as reviewed recently (13), must be regarded as the first step towards the biological attitude of investigating their general or special role in different glycosubstances, a spectrum which reaches from the submaxillary mucins to the antifreeze-glycoprotein of the antarctic fishes and to the serum glycoproteins described here (13).

All these relationships, also with respect to the alkalistable carbohydrate chains, are summarized in figure 2, which includes the biochemical and serological properties of glycoproteins and their "homing" by liver membraneintegrated lectins. Blocking and inhibition studies of the latter will provide further information on the metabolism of glycoproteins; such experiments may also be performed with other glycosubstances of similar structure.

\begin{tabular}{|c|c|c|c|}
\hline Carbohydrate chains & Alkali-labile & Alkali-labile and alkali-stable & Alkali-stable \\
\hline Typical examples & Mucin-type, anti-freeze-type & $\begin{array}{l}\text { Membrane glycoproteins, } \\
\text { Serum glycoproteins }\end{array}$ & $\begin{array}{l}\text { Most serum glycoproteins } \\
\text { (see this paper) }\end{array}$ \\
\hline $\begin{array}{l}\text { End-group after } \\
\text { neuraminidase treatment }\end{array}$ & $\begin{array}{l}\mathrm{Gal} \stackrel{1-3}{\vec{\beta}} \text { GalNac } \\
\mathrm{GalNac} \underset{\vec{\alpha}}{\rightarrow} \mathrm{Thr}_{\mathrm{Thr}}\end{array}$ & $\mathrm{Gal} \underset{\beta}{\stackrel{1-4}{\rightarrow}} \mathrm{Glcl}$ & \\
\hline $\begin{array}{l}\text { Trivial name of } \\
\text { serological specificity }\end{array}$ & $\begin{array}{ll}\text { Anti-TF } & \text { (I) } \\
\text { Anti-A-like }\end{array}$ & Anti-pneumoc & us Type XIV cross reactivity \\
\hline $\begin{array}{l}\text { Lectin receptor } \\
\text { (plant and invertebrate) }\end{array}$ & $\begin{array}{ll}\text { Helix pomatia } & \text { (II) } \\
\text { Arachis hypogaea } & \text { (I) } \\
\text { Agaricus bisporus } & \text { (I) }\end{array}$ & $\begin{array}{l}\text { Phaseolus vulg } \\
\text { Abrus precator } \\
\text { Tridacna maxi }\end{array}$ & \\
\hline $\begin{array}{l}\text { Lectin receptor } \\
\text { (membrane) } \\
\text { (vertebrate) }\end{array}$ & $\begin{array}{l}\text { Liver? } \\
\quad \text { inhibition? }\end{array}$ & $\stackrel{\text { Liver }}{\longrightarrow}$ competitio & \\
\hline
\end{tabular}

Fig. 2. Classification of glycoproteins with respect to their alkali-labile and alkali-stable carbohydrate chains.

\section{References}

1. Uhlenbruck, G., Baldo, B. A., Steinhausen, G., Schwick, H. G., Chatterjee, B. P., Hơ̌ejši, V., Krajhanzl, A. \& Kocourek, J. (1978), this J. 16, 19-23.

2. Uhlenbruck, G., Newman, R. A., Steinhausen, G. \& Schwick, H. G. (1977), Z. Immun. Forsch. 15:3, 183-187.

3. Ashwell, G. \& Morell, A. G. (1977), TIBS April, 76-78.
4. Ashwell, G. \& Morell, A. G. (1974), Adv. Enzymol. 41, 99-124.

5. Salfner, B. (1971), this J. 9, 486-488.

6. Sweeley, C. C., Bentley, R., Makita, M. \& Wells, W. W. (1963), J. Am. Chem. Soc. 85, 2497-2507.

7. Newman, R. A., Harrison, R. \& Uhlenbruck, G. (1976), Biochim. Biophys. Acta 433, 344-356. 
8. Böhm, P., Dauber, St.\& Baumeister, L. (1954), Klin. Wochenschr. 32, 289-292.

9. Lloyd, K. O. \& Kabat, E. A. (1969), Carbohydr. Res. 9, 41-48.

10. Mayo, J. W. \& Carlson, D. M. (1970), Carbohydr. Res. 15, 300-303.
11. Iyer, R. N. \& Carlson, D. M. (1971), Arch. Biochem. Biophys. 142, 101-105.

12. Bertram, G. (1977), Dissertation, Medical Faculty, University of Cologne.

13. Vaith, P. \& Uhlenbruck, G. (1978), Ż. İmmun. Forsch. 154, 1-14.

Prof. Dr. G. Uhlenbruck

Abt. Immunbiologie

Kerpener Straße 15

D-5000 Köln 41 